\title{
Influence of passion fruit albedo, citric acid, and the pulp/sugar ratio on the quality of banana preserves
}

\author{
Influência do teor de albedo de maracujá, do ácido cítrico e da relação polpa/açúcar sobre a qualidade de \\ doce de banana
}

Igor Galvão SILVA ${ }^{1 \star}$, Glêndara Aparecida de Souza MARTINS ${ }^{1}$, Soraia Vilela BORGES ${ }^{1}$, Gerson Reginaldo MARQUES ${ }^{1}$, Itamar Souza REGIS ${ }^{1}$

\begin{abstract}
The objective of this research was to evaluate the effect of the citric acid concentration, pulp/sugar ratio, and albedo concentration of the passion fruit peel on physical, physiochemical, and sensorial characteristics of the 'Silver' banana preserves. A $2^{3}$ factorial design and 3 repetitions in the central point were used. The albedo concentration between 0 and $3 \%$ had significant influence on the reduction of the reducing sugars and on the decrease in titratable acidity. The increase in the pulp/sugar ratio exerted a negative effect on the $\mathrm{pH}$ and positive on the titratable acidity; the acid addition reduced the non-reducing sugar level. The sensorial evaluation and purchase intention indicated that the incorporation of a maximum of $1.5 \%$ albedo in formulations containing $50 \%$ pulp and $0.5 \%$ citric acid resulted in products with good acceptability in comparison with the formulation in which $60 \%$ pulp and an absence of acid or albedo is utilized.

Keywords: fruits, residues, quality, preservation.
\end{abstract}

\section{Resumo}

O objetivo desta pesquisa foi avaliar o efeito da concentração de ácido cítrico, a relação polpa/açúcar e a concentração de albedo da casca de maracujá sobre características físicas, físico-químicas e sensoriais dos doces da banana 'Prata'. Utilizou-se um planejamento fatorial $2^{3}$ com 3 repetições no ponto central. A concentração de albedo entre 0 e $3 \%$ teve influência significativa na redução dos açúcares redutores e na diminuição da acidez titulável. O aumento da razão polpa/açúcar exerceu um efeito negativo em relação ao pH e positivo em relação à acidez titulável, a adição de ácido teve influência negativa no teor dos açúcares não redutores. As análises sensoriais e a intenção de compra indicaram que a incorporação de $1,5 \%$ de albedo nas formulações contendo $50 \%$ de polpa e $0,5 \%$ de ácido cítrico tiveram ótima aceitabilidade, quando comparadas com a formulação que continha $60 \%$ de polpa e ausência de albedo e ácido cítrico.

Palavras-chave: frutas; resíduos; qualidade; conservação.

\section{Introduction}

Brazil, the second largest world producer of banana, is responsible for about $9.5 \%$ of the world production and produced 6,607.000 t of bananas in 2004 and exported 188,087 t, i.e., $2.84 \%$ of the whole production. This small participation in the foreign market is due principally to the high loss index and high domestic consumption of the fruit (BRASIL, 2006).

According to Giovannini (1997), Brazil loses more than US $\$ 1.0$ billion in fruits and vegetables annually. The losses vary widely according to the cultivar explored and technological level employed. A banana cultivar, for example, may reach around $40 \%$ of loss due to its high sensitivity to physical shock and its fast ripening, and therefore adequate for neighborhood marketing. One of the methods to reduce such waste and increase the income of this agribusiness is the use of the surplus fruits or those inappropriate for "in natura" consumption for the production of preserves, which is valuable option for the producers because it means product placement guarantee. The industries also benefit from it since they can use cheaper raw material; this is not a very demanding product in terms of fruit uniformity.

Considerable amount of passion fruit peels are also produced as a result of the industrialization of the juice and for being a pectin rich material, especially since they have already been used in the production of preserves (OLIVEIRA, 2002).

Alternative uses of the albedo as a pectin source in fruit jams have not yet been researched. Hence, the objective of this study is to evaluate its use in the quality of "Silver" banana preserves.

\section{Materials and methods}

\subsection{Preserve processing}

Figure 1 illustrates the processing stages. The 'Silver' banana (yellow peel and firm) and passion fruit peel were acquired from

${ }^{1}$ Universidade Federal de Lavras - UFLA, CP 806, Sul Alameda 07, casa 26, CEP 77023072, Palmas, TO, Brasil, e-mail: galvaoigor@yahoo.com.br ${ }^{*}$ Corresponding author 
the local market. The banana pulp and the passion fruit peel albedo were manually removed and triturated in an industrial blender. In this experimental process, 11 different preserve formulations were elaborated according to a $2^{3}$ factorial design with 3 central points (BOX; DRAPER, 1987), as shown in the experimental design (Table 1).

The pulp and sugar mixture were previously standardized until obtaining a homogeneous mass that was placed in an open stainless-steel tank (Macanuda, AISI 304, SC, Brazil). The acid was added gradually before the beginning of the concentration process itself, and the remainder of the acid was added before obtaining the final desired concentration, like the passion fruit peel albedo, which was added a little before obtaining the desired concentration. This is because adding total amount of acid at the beginning of the process can cause disruption of pectin chains, and fruit pectin can be affected by the acidity and the binomial time $x$ temperature (MEDINA, 1985). The preserves were processed until the final soluble solids concentration of $74^{\circ} \mathrm{Brix}$, hot packed in rigid polypropylene packaging, and stored under room temperature according to Figure 1.

Table 1. $2^{3}$ Experimental design for the elaboration of 'silver' banana preserves.

\begin{tabular}{cccccccc}
\hline \multirow{2}{*}{ Assays } & \multicolumn{3}{c}{ Codified variables } & & \multicolumn{3}{c}{ Real variables } \\
\cline { 2 - 5 } \cline { 6 - 8 } & $\mathrm{x}_{1}$ & $\mathrm{x}_{2}$ & $\mathrm{x}_{3}$ & & $\mathrm{x}_{1}(\%)$ & $\mathrm{x}_{2}(\mathrm{~m} / \mathrm{m})$ & $\mathrm{x}_{3}(\%)$ \\
\hline 1 & +1 & +1 & +1 & & 1 & $60 / 40$ & 3 \\
2 & -1 & -1 & +1 & & 0 & $40 / 60$ & 3 \\
3 & +1 & -1 & +1 & 1 & $40 / 60$ & 3 \\
4 & -1 & +1 & +1 & 0 & $60 / 40$ & 3 \\
5 & +1 & +1 & -1 & 1 & $60 / 40$ & 0 \\
6 & -1 & +1 & -1 & 0 & $60 / 40$ & 0 \\
7 & +1 & -1 & -1 & 1 & $40 / 60$ & 0 \\
8 & -1 & -1 & -1 & 0 & $40 / 60$ & 0 \\
9 & 0 & 0 & 0 & 0.5 & $50 / 50$ & 1.5 \\
10 & 0 & 0 & 0 & 0.5 & $50 / 50$ & 1.5 \\
11 & 0 & 0 & 0 & 0.5 & $50 / 50$ & 1.5 \\
\hline$x_{1}=$ concentration of citric acid (\%); $\mathrm{x}_{2}=$ pulp/sugar ratio (m/m) and $\mathrm{x}_{3}=$ Albedo \\
concentration (\%).
\end{tabular}

\subsection{Experimental design}

The purpose of the design was to evaluate the influence of three factors, the citric acid concentration, the pulp/sugar ratio, and the albedo concentration as a pectin source (independent variables), on the response variables $\mathrm{pH}$, titratable acidity (TA), non-reducing sugars (NRS), reducing sugars (RS), water activity $(\mathrm{Aw})$, yield $(\mathrm{Y})$, firmness $(\mathrm{FI})$, cohesiveness $(\mathrm{CO})$, elasticity (EL), adhesiveness (AD), and fracturabilty (FR). Using the Statistica 5.0 software (Tulsa, Oklahoma, USA), a lineal model was estimated including the interaction effect according to Equation 1.

$Y=\beta 0+\beta 1 x_{1}+\beta 2 x_{2}+\beta 3 x_{3}+\beta 12 x_{1} x_{2}+\beta 13 x_{1} x_{3}+\beta 23 x_{2} x_{3}+\varepsilon(1)$

Where $\beta n$ are the regression coefficients, $\mathrm{Y}$ is the response in question, $\mathrm{x}_{1}, \mathrm{x}_{2}$, and $\mathrm{x}_{3}$ are the codified independent variables (citric acid concentration, pulp/sugar ratio, and albedo concentration as pectin source) according to Table 1 , and $\varepsilon$ is the experimental error. The criterion used to accept the proposed model was given by the high determination coefficient $\left(\mathrm{R}^{2}\right)$ value, assumed as a value exceeding $70 \%$, leading to the conclusion that the model explains a high percentage of the total variability. The coefficient estimates' significance was analyzed aiming at verifying which factor better contributed to the adjustment of the model considering a 5\% level of significance.

\subsection{Chemical and physicochemical p analyses \\ $p H$}

The $\mathrm{pH}$ was determined using a digital potentiometer (Quimis, Q-400A, SP, Brazil) calibrated with a 4.0 and a 7.0 buffer solution (ASSOCIATION..., 1992).

\section{Titratable acidity}

The titratable acidity was determined by titration with $\mathrm{NaOH} 0,1 \mathrm{~N}$ and expressed as an equivalent of citric acid per $100 \mathrm{~g}$ of sample (ASSOCIATION..., 1992).

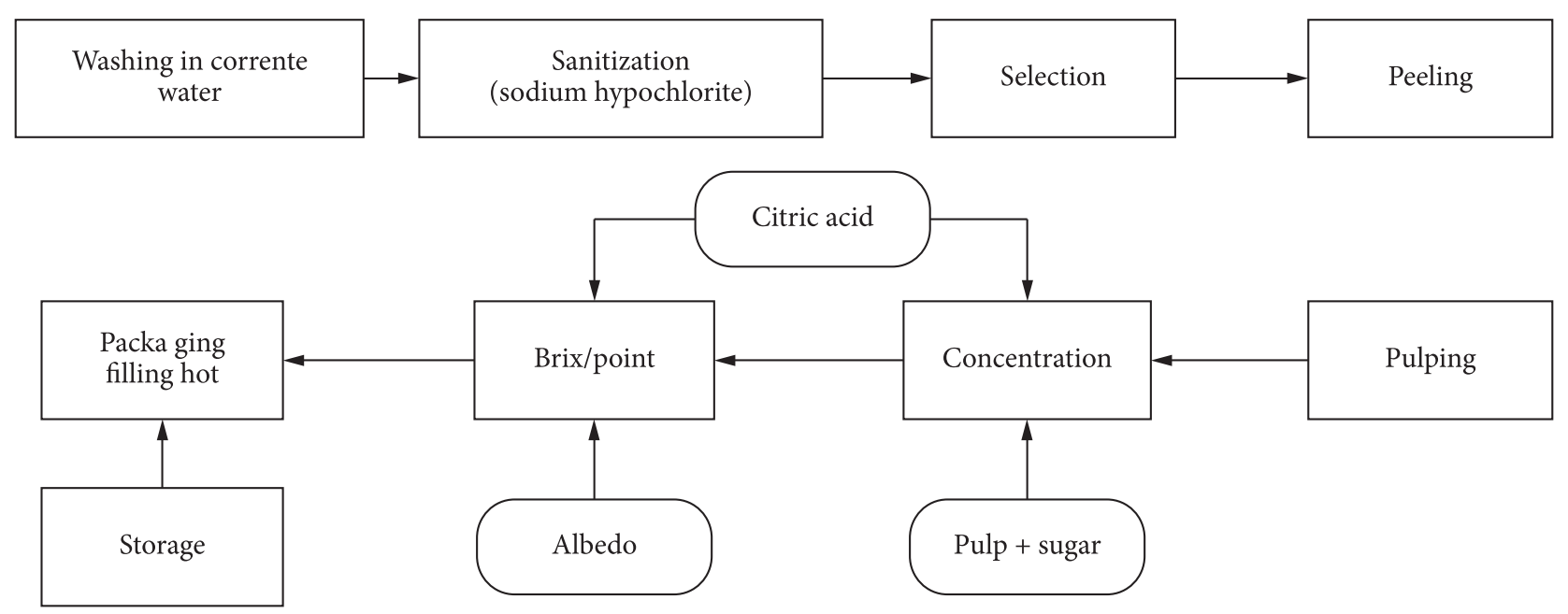

Figure 1. Flowchart of the processing of 'silver' banana preservers. 


\section{Reducing and non-reducing sugars}

The analyses were carried out using the SOMOGYI method adapted by NELSON (ASSOCIATION..., 1992). All of the assays were performed using a Cary 50 spectrophotometer (Varian, SP, Brazil), with absorbance readings at $510 \eta \mathrm{m}$.

\section{Water actdivity - Aw}

The water activity was determined using an Aqualab equipment (Decagon, 3TE, Device, Pullman, WA). Approximately $5 \mathrm{~g}$ of the sample were placed in plastic containers, and the readings were taken at an average temperature of $25.0^{\circ} \mathrm{C}$.

\section{Texture profile analysis (TPA)}

The analyses were conducted at the Microstruture Laboratory with a texturometer (Stable Micro Systems, TAXT2i, Goldaming, England) with an acrylic cylindrical flatbottomed probe $(\varnothing=6 \mathrm{~mm})$ and duration, distance, pre-test, test, and post-test speeds of 5 seconds, $6 \mathrm{~mm}, 2,1$ and $4 \mathrm{~mm} / \mathrm{s}$, respectively. The parameters analyzed were: firmness (FI), cohesiveness (CO), elasticity (EL), adhesiveness (AD), and fracturabilty (FR). The results were expressed as the averages of 5 determinations.

\section{Yield calculation}

The yield of the preserves was calculated in relation to the amount of pulp by the Equation 2 .

$\% \mathrm{R}=(P f \times 100) / P i$

Where:

- $\% \mathrm{R}=$ yield percentage of the preserves

- $P i=$ pulp mass $(\mathrm{kg})$

- $P f=$ mass of preserves after processing $(\mathrm{kg})$

- All analyses were carried out in triplicate.

Sensory analysis

The sensory analysis was conducted at the Sensory Analysis Laboratory, and the samples were evaluated using acceptance tests to the attributes of taste, texture, global impression, and purchase intention. A nine point structured hedonic scale was used according to the following hedonic ratings: $1=\mathrm{I}$ extremely disliked and $9=$ I extremely liked for the attributes of taste, texture, and global impression. For purchase intention a structured five point scale was used, anchored by the hedonic ratings: $1=$ I certainly would not buy and $5=$ I certainly would buy. The sensory analysis was performed with 42 non-trained testers in individual booths, and the 11 banana preserve samples were served in three sessions $(4,4,3)$ with an interval of at least 1 hour between the sessions; all testers tasted all samples. In order to avoid the effect that a sample can cause on the other, the test was carried out in individual booths using disposable $50 \mathrm{~mL}$ plastic cups coded with three-digit numbers (STONE; SIDEL, 2005). The results of the sensory analysis were evaluated by multiple comparison of means using the Tukey test at $5 \%$ ( $\mathrm{p}<0.05$ ) using the SISVAR program (analysis system of variance for balanced data) (FERREIRA, 1999).

\section{Results and discussion}

\subsection{Physical and chemical analyses}

The results of the physical and chemical analyses and the yield of the formulations are summarized in Table 2.

In the full models, the non-significant coefficients were eliminated resulting in the adjusted models with the use of coded variables (Table 3 ). The adequacy of complete models can be verified by the coefficients of determination $\left(\mathrm{R}^{2}\right)$ explaining between 70 to $98 \%$ of the total variance of responses.

The addition of the albedo had a significant influence on the decrease of the titratable acidity (Figures 2a,b). This influence is probably related to the acidity of the albedo, which is around $0.20 \%$, thus contributing to the reduction of the response (MACHADO et al., 2003).

The increase of the pulp/sugar ratio also exerted a positive effect on the titratable acidity of the preserves (Figure $2 \mathrm{a}$ ) and a negative effect on the $\mathrm{pH}$ (Figure 3), which might have been due to the titratable acidity of the banana pulp. The maturation stage is one of the main factors that affect acidity, the two factors were positively correlated over time (HEWAGE et al., 1995). Nascimento Junior (2008) found values ranging between 0.17

Table 2. Averages of physical-chemical and physical analyses and yield of 'silver' banana preserves.

\begin{tabular}{|c|c|c|c|c|c|c|c|c|c|c|c|}
\hline \multirow[t]{2}{*}{ Responses } & \multicolumn{11}{|c|}{ Assays } \\
\hline & F.1 & F.2 & F.3 & F.4 & F.5 & F.6 & F.7 & F.8 & F.9 & F.10 & F.11 \\
\hline Titratable acidity (g ac. Citric. $100 \mathrm{~g}^{-1}$ ) & 0.8 & 0.4 & 0.53 & 0.36 & 0.84 & 0.47 & 0.57 & 0.3 & 0.57 & 0.58 & 0.575 \\
\hline Non-reducing sugar $\left(\mathrm{g} .100 \mathrm{~g}^{-1}\right)$ & 28.66 & 30.26 & 27.20 & 27.82 & 13.86 & 21.93 & 23.27 & 46.04 & 28.83 & 29.49 & 31.08 \\
\hline Reducing sugar (g.100 g- $\left.{ }^{1}\right)$ & 13.91 & 24.81 & 24.13 & 23.61 & 24.77 & 19.41 & 33.77 & 11.14 & 21.54 & 23.10 & 19.91 \\
\hline Water activity (wa) & 0.66 & 0.699 & 0.733 & 0.687 & 0.678 & 0.731 & 0.703 & 0.784 & 0.642 & 0.654 & 0.643 \\
\hline $\mathrm{Ph}$ & 3.7 & 4.6 & 3.61 & 4.56 & 3.62 & 4.39 & 3.53 & 3.96 & 3.96 & 3.97 & 3.96 \\
\hline Yield (\%) & 60.7 & 71.83 & 69.56 & 68.11 & 56 & 63.5 & 77.28 & 85.25 & 59.41 & 56.96 & 56.96 \\
\hline Adhesiveness (N) & 4.749 & 2.046 & 5.85 & 3.299 & 2.327 & 4.538 & 3.917 & 4.687 & 3.364 & 3.756 & 3.123 \\
\hline Cohesiveness (N) & 0.352 & 0.742 & 0.875 & 0.533 & 0.542 & 0.523 & 0.791 & 0.727 & 0.681 & 0.693 & 0.703 \\
\hline Elasticity (N) & 0.938 & 0.91 & 0.954 & 0.946 & 0.96 & 0.973 & 0.929 & 0.970 & 0.967 & 0.959 & 1.255 \\
\hline Firmness (N) & 4.628 & 2.511 & 4.46 & 2.86 & 1.679 & 3.232 & 2.841 & 2.26 & 2.387 & 2.254 & 2.793 \\
\hline Fraturabilty $(\mathrm{N})$ & 0.199 & 0.198 & 0.2 & 0.199 & 0.197 & 0.199 & 0.199 & 0.197 & 0.197 & 0.198 & 0.2 \\
\hline
\end{tabular}


Table 3. Regression equations with codified variables, significance and, coefficients of determination of the complete models for the responses in the physical and physicochemical analyses and yield of 'silver' banana preserves.

\begin{tabular}{|c|c|c|c|}
\hline Response & Model estimator & Prob $>$ F & $\mathrm{R}^{2}$ \\
\hline Titratable acidity (g citric ac. $100 \mathrm{~g}^{-1}$ ) & $0.54+0.15 \mathrm{x}_{1}+0.09 \mathrm{x}_{2}+0.04 \mathrm{x}_{2} \mathrm{x}_{3}$ & 0.038 & 0.979 \\
\hline Non-reducing sugar $\left(\mathrm{g} .100 \mathrm{~g}^{-1}\right)$ & $28.043-4.132 \mathrm{x}_{1}-3.704 \mathrm{x}_{2}+4.677 \mathrm{x}_{1} \mathrm{x}_{2}-3.578 \mathrm{x}_{1} \mathrm{x}_{3}$ & 0.0029 & 0.973 \\
\hline Reducing sugar (g.100 g-1) & $21.827+2.201 \mathrm{x}_{1}-4.796 \mathrm{x}_{1} \mathrm{x}_{3}-3.586 \mathrm{x}_{2} \mathrm{x}_{3}$ & 0.041 & 0.923 \\
\hline Water activity (wa) & 0.69 & 0.0000 & 0.461 \\
\hline $\mathrm{Ph}$ & $4.06-0.48 \mathrm{x}_{1}$ & 0.0000 & 0.969 \\
\hline Yield (\%) & 65.69 & 0.0000 & 0.661 \\
\hline Adhesiveness (N) & $3.787+1.029 \mathrm{x}_{1} \mathrm{x}_{3}$ & 0.005 & 0.913 \\
\hline Cohesiveness $(\mathrm{N})$ & 0.651 & 0.0001 & 0.7 \\
\hline Elasticity $(\mathrm{N})$ & 0.978 & 0.0000 & 0.448 \\
\hline Firmness $(\mathrm{N})$ & 2.897 & 0.0001 & 0.782 \\
\hline
\end{tabular}

$\mathrm{x}_{1}=$ citric acid concentration (\%); $\mathrm{x}_{2}=$ pulp/sugar ratio $(\mathrm{m} / \mathrm{m})$ and $\mathrm{x}_{3}=$ albedo concentration (\%).

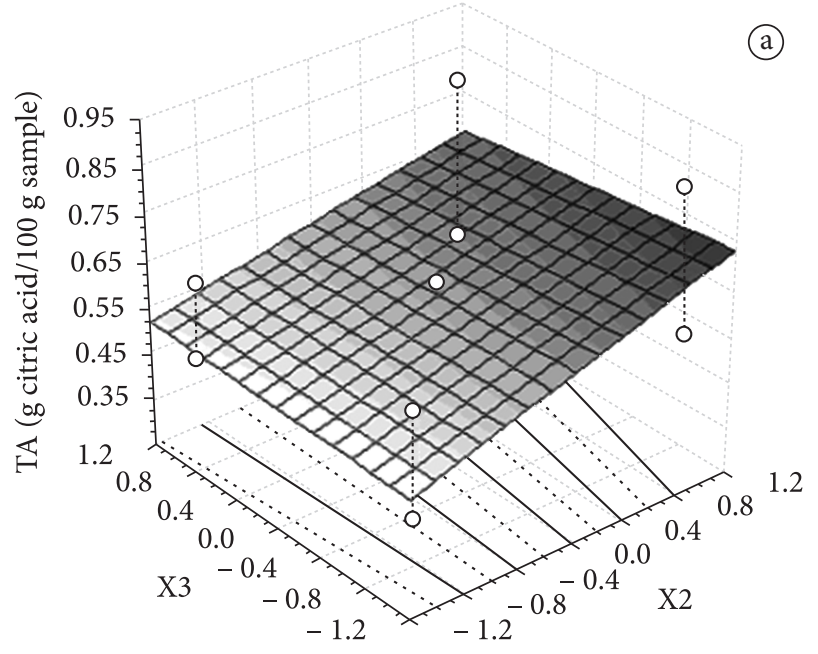

\begin{tabular}{|lllllll|}
\hline$\square 0.445$ & $\square 0.468$ & $\square 0.491$ & $\square 0.513$ & $\square 0.536$ & $\square 0.558$ \\
$\square 0.581$ & $\square 0.604$ & $\square 0.626$ & $\square 0.649$ & $\square 0.672$ & $\square$ Above \\
\hline
\end{tabular}

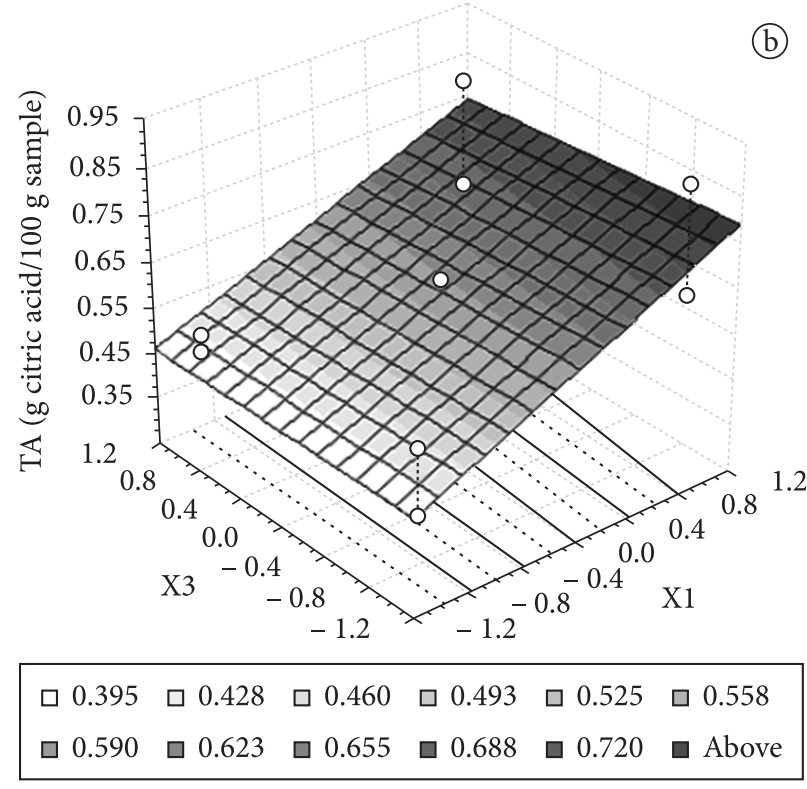

Figure 2. Response surfaces for titratable acidity (ta) for the 'silver' banana preserves. Where $\mathrm{x}_{1}=$ citric acid concentration (\%); $\mathrm{x}_{2}=\mathrm{pulp} /$ sugar ratio $(\mathrm{m} / \mathrm{m})$ and $\mathrm{x}_{3}=$ albedo concentration (\%).
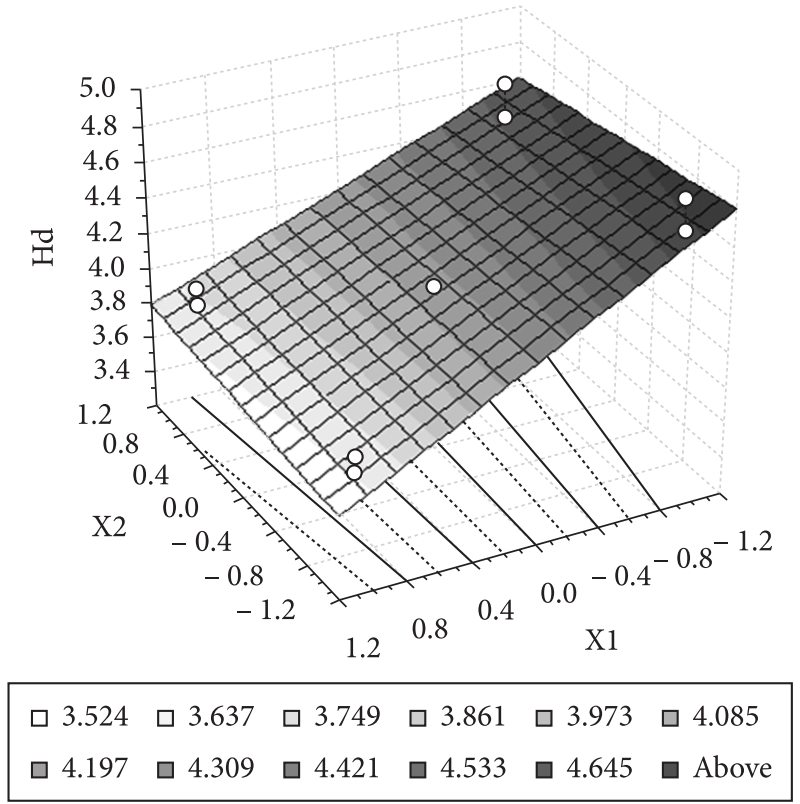

Figure 3. Response surfaces for ph for the 'silver' banana preserves. Where $\mathrm{x}_{1}=$ citric acid concentration $(\%) ; \mathrm{x}_{2}=$ pulp/sugar ratio $(\mathrm{m} / \mathrm{m})$ and $\mathrm{x}_{3}=$ albedo concentration (\%).

and $0.66 \%$ malic acid per $100 \mathrm{~g}$ of fruit at 2 and 14 days of storage, respectively, but these values did not differ statistically by Tukey test at the level of $5 \%$.

The citric acid addition, as expected, increased the titratable acidity (Figure $2 \mathrm{~b}$ ) and reduced the $\mathrm{pH}$ (Figure 3 ) of the preserves. The titratable acidity of different formulations of the preserve ranged from 0.3 to $0.84 \mathrm{~g} .100 \mathrm{~g}^{-1}$ (Table 2). These values remained within the range recommended by Jackix (1988), which describes values ranging from 0.5 to $08 \%$. With regard to the $\mathrm{pH}$, values ranged from 3.61 to 4.6 (Table 2); however, a value around 3.8 would be good for the preserve. This value affects the gel formation, enhance the natural flavor of the fruit, and the inversion of sucrose preventing crystallization (JACKIX, 1988; NOGUEIRA; TORREZAN, 1999).

The increase in the amount of sugar and consequently the reduction of the amount of pulp and the citric acid used in the formulations elevated the non-reducing sugar levels (Figure 4a). 
In Figure $4 \mathrm{~b}$, it can be observed the effect of interaction of citric acid $\left(x_{1}\right)$ and concentration of albedo $\left(x_{2}\right)$, which, according to the model estimator, has a negative effect of $-3.578 \mathrm{x}_{1} \mathrm{x}_{2}$ (Table 3 ) on non-reducing sugar, which may have been due to the acid inversion of the sucrose.

With the increase of the pulp and albedo, there is a reduction in the sucrose and, consequently, less inversion thus reducing the glucose and fructose concentration, the major representatives of the reducing sugars in the preserves (Figure 5b). Studying the use of the pulp of green umbu as an

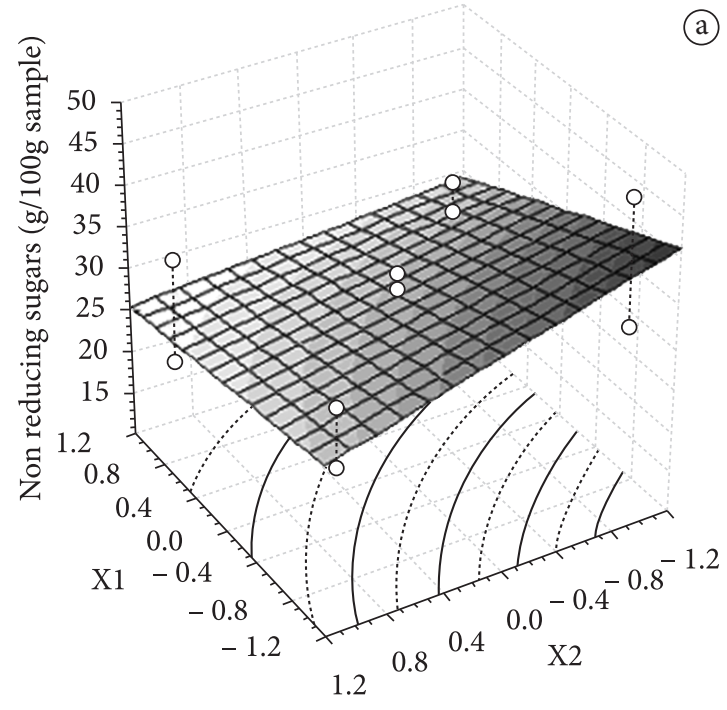

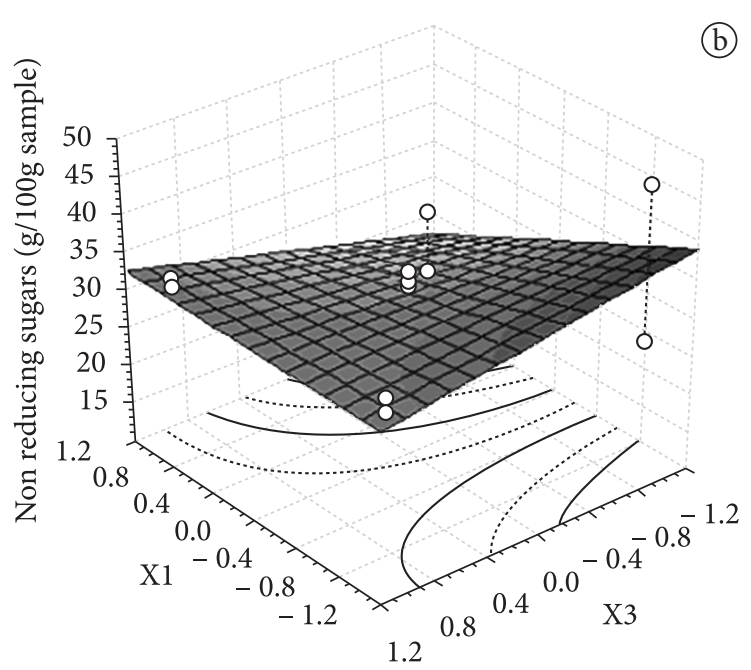

\begin{tabular}{|c|c|c|}
\hline 18.293 & $\square 19.978$ & $\square 21.663$ \\
\hline$\square 25.034$ & $\square 26.719$ & $\square 28.405$ \\
\hline 31.775 & 33.460 & 35.146 \\
\hline
\end{tabular}

Figure 4. Response surfaces for non-reducing sugars for the 'silver' banana preserves. Where $\mathrm{x}_{1}=$ citric acid concentration (\%); $\mathrm{x}_{2}=$ pulp/ sugar ratio $(\mathrm{m} / \mathrm{m})$ and $\mathrm{x}_{3}=$ albedo concentration (\%).

alternative for the production of preserves with the use of a 1/1 polpa/sacarose proportion, Policarpo et al. (2003) determined that the sucrose was not present in the preserves because it was hydrolyzed in an acid medium $(\mathrm{pH}=3.0)$ and under heating. In the present study, at the end of the cooking, the sucrose presence was higher than that of glucose, which means a lower degree of hydrolysis in this process and which is desirable for physical stability of the preserves. According to Jackix (1988), the optimum percentage of inverted sugar is from 35 to $40 \%$ of the total sugars. An excess of inverted sugars ( $50 \%$ of the total

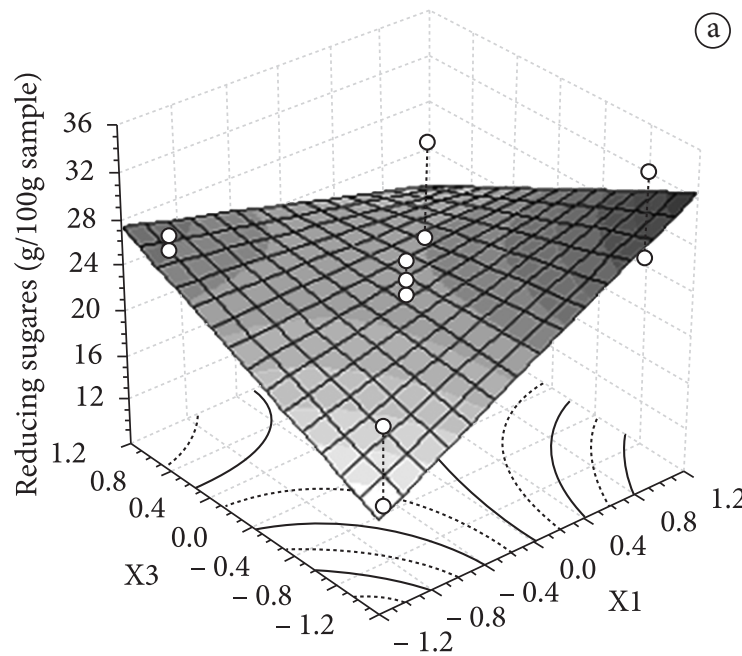

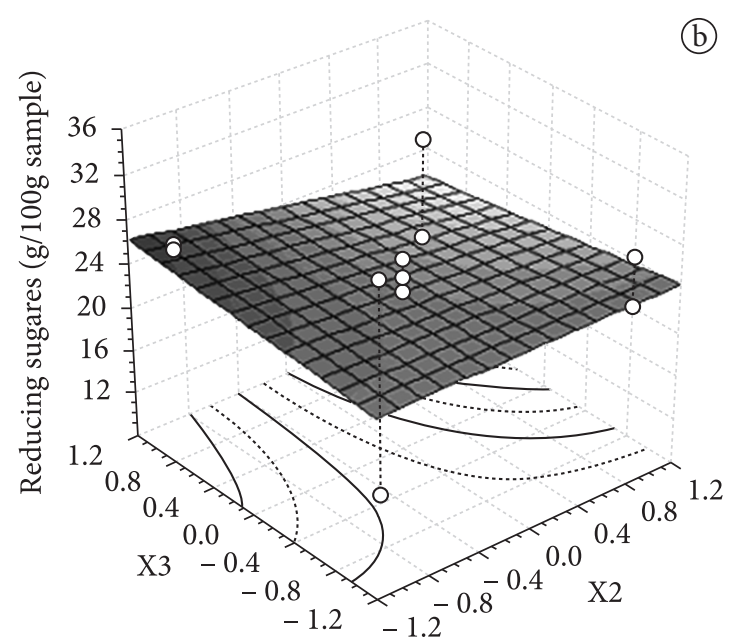

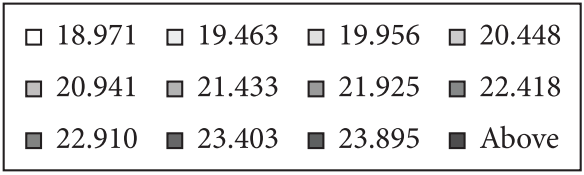

Figure 5. Response surfaces for reducing sugars for the 'silver' banana preserves. Where $\mathrm{x}_{1}=$ citric acid concentration (\%); $\mathrm{x}_{2}=$ pulp/sugar ratio $(\mathrm{m} / \mathrm{m})$ and $\mathrm{x}_{3}=$ albedo concentration $(\%)$. 
solids) can result in dextrose granulation (glucose) in the gel, and the low inversion of the sucrose can cause crystallization.

The acid helps the inversion of the sucrose into glucose and fructose, consequently, with the increase of the acid level there should be an increase in the reducing sugars, which can be seen in Figure $5 \mathrm{a}$.

The graph in Figure 6 is known as a saddle graph, the forms of the level curves indicate the possible existence of a stationary point outside of the experimental area (outlier), i.e., one of the observations presented a reducing sugar value significantly different from the others, which might have occurred due to the influence of the processing which interferes in the sucrose conversion into reducing sugars in addition to the presence of the pectin originating from the passion fruit peel. Damiani et al. (2008) observed that the presence of peels in the formulation of mango jelly causes alteration in the reducing sugars according to the amount and the degree of maturity of the added peel and to the cooking duration. The authors highlight that the addition of peels in the production of jellies and preserves can cause a decrease in the conversion of sucrose into reducing sugars.

None of the studied independent variables presented significant influence on the water activity, firmness, elasticity, cohesiveness, and yield. Apparently, due to the high loss at the end of the process, with residue remaining in the container, there was a change in the yield Most of the determination coefficients $\left(\mathrm{R}^{2}\right)$ were low; as a result, more points (axial points) would be necessary to adjust a model of larger order (2nd degree). However, it is observed that the increase in the albedo concentration makes the preserves firmer. On the other hand, the absence of albedo under less acidic conditions also leads to a firmer preserve. Such a fact is due to the pectin present in the albedo or the reduction of the excessive hydrolysis of nonreducing sugars, keeping in mind that the pectic substances are those that contribute to the invigoration of the gel. Similar results to those of performance of the pectin in the firmness of gels have been related in several studies (ROYER, 2006; POLICARPO et al., 2007; CEREZAL; CASTRO; DUARTE, 2007). In other stidies, it was found that the reduction in the $\mathrm{pH}$ contributed to the firmness increase of the preserves (SOARES JÚNIOR et al., 2003; MARTINS et al. 2007; POLICARPO et al., 2003). This fact can be attributed to lower dissociation of the free carbonyls in the pectin molecules, which reduces the intermolecular repulsion and favors the formation of crossed bonds, essential for the formation of the gel (ALIKONIS, 1979). According to Evangeliou, Richardson and Morris (2001) the glucose syrup, or reducing sugars resulting from the hydrolysis, has higher interaction with the pectin, which favors more rigid gels obtained by intermolecular pectic bonds.

Similarly, the yield is relatively higher with the higher albedo concentration. Among the authors that observed the factors that influence the yield of preserves, Menezes et al. (2008) highlights that the amount of sugar influences the yield of the preserves, and the higher the amount of sugar present in the preserves, the higher the yield because the sugar concentration directly interferes in the level of soluble solids previously determined to indicate the end of the cooking process. Albuquerque (1997), Policarpo et al. (2003) and Martins et al. (2007) made similar observations stating that the gelification time is inversely proportional to the sugar concentration. Therefore, the increase of the addition of sugar leads to a shorter cooking time, less water evaporation, and consequently a higher yield.

\subsection{Sensory analysis}

Table 4 shows the average values of the scores obtained in the acceptance test in the sensory evaluation of the formulations for the attributes of taste, texture, overall aspect, and purchase intent.

The results of the sensory analysis showed significant difference $(p>0.05)$ between the formulations $3,6,7$, and 9 and the formulations 5 and 8 , which had the best and worst average, respectively. The formulations 1, 2, 4, 10, and 11 did

Table 4. Average acceptance of the attributes for the formulations of the different assays.

\begin{tabular}{cccc}
\hline Assay & Flavor & Consistency & Overall aspect \\
\hline 1 & $6.81^{\mathrm{ab}}$ & $6.60^{\mathrm{bc}}$ & $6.64^{\mathrm{abcd}}$ \\
2 & $7.21^{\mathrm{ab}}$ & $6.69^{\mathrm{bc}}$ & $6.93^{\mathrm{bcd}}$ \\
3 & $7.36^{\mathrm{b}}$ & $6.33^{\mathrm{bc}}$ & $6.95^{\mathrm{bcd}}$ \\
4 & $6.98^{\mathrm{ab}}$ & $5.93^{\mathrm{ab}}$ & $6.36^{\mathrm{abc}}$ \\
5 & $6.43^{\mathrm{a}}$ & $6.14^{\mathrm{bc}}$ & $6.14^{\mathrm{ab}}$ \\
6 & $7.50^{\mathrm{b}}$ & $6.88^{\mathrm{bc}}$ & $7.10^{\mathrm{cd}}$ \\
7 & $7.48^{\mathrm{b}}$ & $6.33^{\mathrm{bc}}$ & $7.05^{\mathrm{cd}}$ \\
8 & $6.45^{\mathrm{a}}$ & $5.02^{\mathrm{a}}$ & $5.90^{\mathrm{a}}$ \\
9 & $7.62^{\mathrm{b}}$ & $7.12^{\mathrm{c}}$ & $7.36^{\mathrm{d}}$ \\
10 & $7.24^{\mathrm{ab}}$ & $6.86^{\mathrm{bc}}$ & $7.17^{\mathrm{cd}}$ \\
11 & $7.24^{\mathrm{ab}}$ & $6.83^{\mathrm{bc}}$ & $6.95^{\mathrm{bcd}}$
\end{tabular}

Obs: Averages with the same letters in the same horizontal line are not significantly different from one another at a $5 \%$ level of significance by the Tukey test.

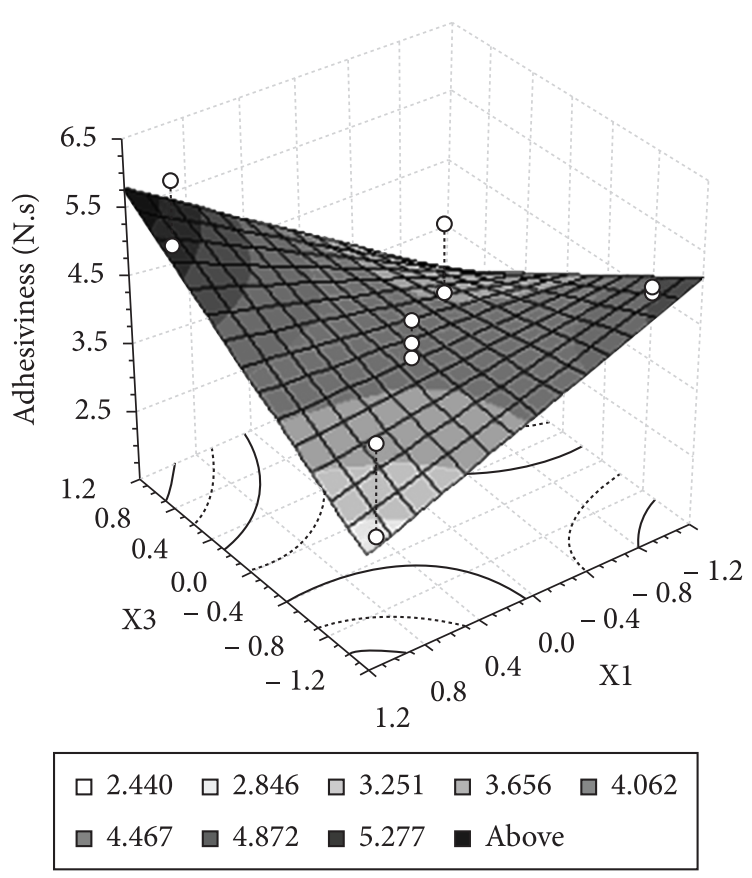

Figure 6. Response surfaces for adhesiveness for the 'silver' banana preserves. Where $\mathrm{x}_{1}=$ citric acid concentration (\%); $\mathrm{x}_{2}=$ pulp/sugar ratio $(\mathrm{m} / \mathrm{m})$ and $\mathrm{x}_{3}=$ albedo concentration $(\%)$. 
not differ statistically from the other formulations in relation to the attribute flavor (Table 4).

With regard to consistency, formulation 9 differs from formulations 8 and 4 . Formulations 1, 2, 3, 5, 6, 7, 10, and 11 did not differ from the others, except for formulation 8 , which showed the lowest average.

Formulation 9 reached an average of 7.36 for the attribute overall aspect; this value differed from formulations 4,5 , and 8. The averages of the formulations $1,2,3,6,7,9,10$, and 11 did not differ amongst themselves, especially formulation 1 that did not differ from the others at the level of $5 \%$ significance.

With regard to intention to purchase, formulations 6 and 9 differ statistically from formulations 4,5 and 8 , with scores close to "probably buy" in the scale used. The remaining samples were found to be within the range set from the middle of the scale to the point "I probably would not buy". Among all formulations, formulation 6 was the one with the best performance; $45.16 \%$ of the tasters would certainly buy the product.

According to Teixeira; Meinert and Barbetta (1987), for a product to be considered as accepted in terms of its sensorial properties, it is necessary that it obtains an acceptability index of at least $70 \%$, and in this case formulations 6 and the central points $(9,10$, and 11) obtained good acceptability for all of the analyzed attributes.

\section{Conclusion}

The results indicate that the albedo concentration between 0 and $3 \%$ had significant influence on the reduction of the reducing sugars and on the decrease of the titratable acidity due to its low acidity. The pulp/sugar ratio and the citric acid concentration were the most relevant variables in the process influencing the acidity, $\mathrm{pH}$, and reducing and non-reducers sugars as well as the addition of the acid.

The sensorial evaluation and purchase intention indicated that the inclusion of a maximum $1.5 \%$ albedo in the formulations containing $50 \%$ pulp and $0.5 \%$ citric acid resulted in products of good acceptability in comparison with the formulation in which $60 \%$ pulp and an absence of acid or albedo is utilized.

\section{Acknowledgments}

The authors are grateful for the financial support provided by FAPEMIG EDT 2414/05.

\section{References}

ALBUQUERQUE, J. P. Fatores que influenciam no processamento de geléias e geleiadas de frutas. Boletim da Sociedade Brasileira de Ciência e Tecnologia de Alimentos, v. 31, n. 1, p. 62-67, 1997.

ALIKONIS, J. J. Starch and pectin jellies. In: Candy technology. Connecticut: AVI, p. 109-118, 1979.

ASSOCIATION OF OFFICIAL ANALITICAL CHEMISTRY - AOAC. Official méthods of analysis of the association of analitical chemistry. 11. ed. Washington, 1992. $115 \mathrm{p}$.

BRASIL. Ministério da Agricultura e do Abastecimento. Secretaria de Produção e Comercialização. Departamento de Comercialização. Balança comercial do agronegócio. Brasília. Disponível em: $<$ http: |lwww.agricultura.gov.Br>. Acesso em: dez. 2009.
BOX, G. E. P.; DRAPER, N. R. Empirical model-building and response surfaces. New York: J. Willey \& Sons, 1987. 669 p.

CEREZAL, P.; CASTRO, E.; DUARTE, G. A. Reseach note on rheological behaviour of some processed products from cactus pear (Opuntia Ficus-Indica L. Mill.). Journal Texture Studies, v. 38, p. 738-754, 2007. http://dx.doi.org/10.1111/j.1745-4603.2007.00123.x

DAMIANI, C. et al. Análise física, sensorial e microbiológica de geléias de manga formuladas com diferentes níveis de cascas em substituição à polpa. Revista Ciência Rural, v. 38, n. 5, p. 1418- 1423, 2008. http://dx.doi.org/10.1590/S0103-84782008000500035

FERREIRA, D. F. Sistema para análise de variância para dados balanceados - SISVAR. Lavras: UFLA, 1999. 92 p.

EVANGELIOU, V.; RICHARDSON, R. K.; MORRIS, E. R. Effect of $\mathrm{pH}$, sugar type and thermal annealing on high-methoxy pectin gels. Food Chemistry, v. 73, p. 85-91, 2001.

GIOVANNINI, E. Aproveitamento de resíduos da industrialização de frutas. Agropecuária Catarinense, v. 10, n. 2, 1997. 67 p.

HEWAGE, K. S.; WAINWRIGHT, H.; LUO, Y. Effect of ethanol and acetaldehyde on banana ripening. Journal of Horticultural Science, v. 70, n. 1, p. 51-55, 1995.

JACKIX, M. H. Doces, geléias e frutas em calda. Campinas: Unicamp, 1988. 85 p.

MACHADO, S. S. et al. Caracterização física e físico-química de frutos de maracujá amarelo provenientes da região de Jaguaquara. Magistra, v. 15, n. 2, 2003. Disponível em: <http://www.magistra.ufrb.edu.br/ publica/magist15_2_frut/03-15_2-04c.html> Acesso em: maio 2010.

MARTINS, M. L. A. et al. Características de doces em massa de umbu verde e maduro e aceitação pelos consumidores. Pesquisa Agropecuária Brasileira, v. 42, n. 9, p. 1329-1333, 2007. http:// dx.doi.org/10.1590/S0100-204X2007000900015

MEDINA, J. C. Cultura da banana: cultura, matéria prima, processamento e aspectos econômicos. Campinas: ITAL, 1985. 131 p.

MENEZES, C. C. Otimização e avaliação da presença de sorbato de potássio e das embalagens sobre o doce de goiaba durante o armazenamento. 2008. 120 f. Dissertação (Mestrado em Ciência dos Alimentos) - Universidade Federal de Lavras, Lavras, 2008.

NASCIMENTO JUNIOR, B. B. et al. Diferenças entre bananas de cultivares Prata e Nanicão ao longo do amadurecimento: características físico-químicas e compostos voláteis. Ciência e Tecnologia de Alimentos, v. 28, n. 3, p. 649-658, 2008. http://dx.doi. org/10.1590/S0101-20612008000300022

NOGUEIRA, R. I.; TORREZAN, R. Processamento e utilização. In: ALVES, E. J. (Org.). A cultura da banana: aspectos técnicos, socioeconômicos e agroindustriais. 2. ed. Brasília: Embrapa, p. 545-585, 1999.

OLIVEIRA, L. F. et al. Aproveitamento alternativo da casca do maracuja-amarelo (Passiflora edulis F. Flavicarpa) para produção de doce em calda. Ciência e Tecnologia de Alimentos, Campinas, v. 22, n. 3, p. 259-262, 2002.

POLICARPO, V. M. N. et al. Efeito de aditivos sobre el color, textura y aceptación del dulce de umbu (Spondias tuberosa, Arr. Cam.) verde. Alimentaria, n. 346, p. 111-115, 2003.

ROYER, G. et al. Preliminary studies of the production of the production of apple pomace and quince jelly. LWT - Food Science and Technology, v. 39, n. 9, p. 1022-1025, 2006.

SOARES JÚNIOR, A. M.; MAIA, A. B. R. A.; NELSON, D. L. Estudo do efeito de algumas variáveis de fabricação no perfil de texturométrico do doce de manga. Ciência e Tecnologia de Alimentos, v. 23, n. 1, p. 76-80, 2003.

STONE, H.; SIDEL, J. Sensory evaluation practices. 3rd. ed. New York: Academic Press, 2005. 377 p.

TEIXEIRA, E.; MEINERT, E.; BARBETTA, P. A. Análise sensorial dos alimentos. Florianópolis: Editora da UFSC, 1987. 182 p. 